\title{
Developing an intranet towards knowledge sharing: a practitioner-based inquiry
}

\author{
U.R. Averweg \\ Information Services \\ eThekwini Municipality and University of KwaZulu-Natal \\ Durban, South Africa \\ averwegu@durban.gov.za
}

The intranet is a common feature in many organizations. With the increasing use of a technology infrastructure in organizations, there is a continued challenge for employees in an organization to contribute their knowledge willingly and to make use of knowledge sharing with other employees. Intranets are well-suited for use as a strategic tool in knowledge sharing due to their ability to support the distribution, connectivity and publishing of data and information. Intranets should be seen as integral to an organization's knowledge management strategy and should be tailored to suit and enhance an organization's knowledge-sharing activities. The question arises: To what extent does an organization's existing intranet facilitate knowledge sharing? From a practitioner-based inquiry perspective, this question was explored by the selection of a large organization - eThekwini Municipality, Durban, South Africa - as the field of application. Derived from a mixed methodology approach, the results of a survey are presented. It is suggested that encouragement be given for more practitioner-based inquiry research.

Key words: Intranet technology, knowledge, knowledge management, knowledge sharing, practitioner research

Received 18 January 2008; accepted 15 February 2008

\section{Contents}

1. Introduction

2. Background

3. Intranet and intranet technology

4. Knowledge and managing knowledge

5. Knowledge management (KM)

6. eThekwini Municipality in South Africa

7. Research methodology

8. Research method

9. Results and discussion

10. Conclusion

11. References

\section{Introduction}


The intranet is a common feature in many organizations. With the increasing use of a technology infrastructure in organizations, there is a continued challenge for employees in an organization to contribute their knowledge willingly and to make use of knowledge sharing with other employees. World-Wide Web (the Web) technology has provided a common technological infrastructure to support the collective management of knowledge in organizations (Khosrow-Pour 2005). The intranet is based on Web technology. An intranet can provide useful and people-inclusive knowledge management (KM) environments (Stenmark 2002). Van der Walt, van Brakel and Kok (2004:4) suggest that 'it is important that an organization's intranet should be evaluated regularly'.

Given that advances in information technology (IT) have made it easier to acquire, store and disseminate knowledge than ever before, many organizations are employing IT to facilitate the sharing and integration of knowledge (Kankanhalli, Tanudidjaja, Sutanto and Tan, 2003:69). Knowledge in organizations should be viewed as a resource for knowledge sharing. Knowledge sharing is defined as 'the willful application of one's ideas, insights, solutions, experiences (i.e. knowledge) to another individual either via an intermediary, such as a computer-based system, or directly' (Turban, McLean, Wetherbe 2004:457). The question arises: To what extent does an organization's computer-based system, such as an intranet, facilitate knowledge sharing? This was the research objective of this study.

This research study was a practitioner-based inquiry. Practitioner-research can be identified as 'a systematic form of enquiry that is collective, collaborative, self-reflective, critical and undertaken by the participants of the inquiry' (McCutcheon and Jung 1990). In a practitionerresearch culture, individual enquiry is encouraged (Bevan 2006:67). The underlying question on the mind of any practitioner researcher is: How can the researcher improve what is happening in a selected environment? Given that the author is employed as an IT research analyst at eThekwini Municipality and he actively participates in contents and contribution to academic conferences and journals, it is contended that he was 'qualified' to undertake a practitioner-based inquiry.

\section{Background}

There is a need for knowledge-sharing practices in the workplace to enable managers to promote the sharing of knowledge and allow the organization to acquire and retain intellectual capital (IC). To what extent does an organization's existing intranet facilitate knowledge sharing? For example, eThekwini Municipality in South Africa is 'committed to using Information Technology to make a real difference ... municipal decisions have to be based on sound research and information management in order to ensure [service] delivery' (eThekwini Municipality 2006:28). KM initiatives in organizations are increasingly becoming important as organizations are making significant IT investments in deploying KM systems (Hahn and Subramani 2000:302).

Arising from the eThekwini Municipality's 2020 vision, a long-term development framework was developed (see Website www.durban.gov.za). The Municipal Systems Act No. 132 of 2000 requires all municipalities to develop integrated development plans (IDPs). Eight specific outcomes were formulated for the IDP to achieve the eThekwini Municipality's vision. One of the specific goals of Plan 5 (empowering our citizens) is 'to determine the strategy and structures needed to implement the process of becoming a "Learning Organization"'. Within Plan 5, are three strategic focus areas (SFAs): SFA1, SFA2 and SFA3. Programme 7 of SFA1 states as follows:

\section{'Improve knowledge management in the municipality}


The retention of institutional knowledge is a key factor in the development of an organization and this long term programme intends to increase the general awareness of the meaning and value of knowledge management within the Municipality' (eThekwini Municipality Integrated Development Plan 2007:65).

Skyrme (1998) suggests that the first KM initiative 'of many companies (between a third and a half according to surveys) is that of installing or improving an Intranet'. Intranets provide the technological platform for recording organizational knowledge (Debowski 2006:145).

As employees in an organization (such as eThekwini Municipality) reach retirement age, their (valuable) tacit knowledge may never be 'captured' or 'stored' in any form and this IC is then lost to the organization. Since this knowledge artifact is not retrievable, it cannot be shared within the organization. Expert knowledge is hard to duplicate, replace or interpret as it is grounded in a blend of research and induction which may have been redefined over many years (Debowski 2006:18). Often the following comment is cited: 'If only we knew what we knew'. There is thus a need to make better use of and manage the knowledge that already exists within the eThekwini Municipality; for example, by shared learnings and technical solutions and minimizing the future IC 'brain drain' to the organization.

\section{Intranet and intranet technology}

An intranet (or internal Web) is a network designed to serve the internal informational needs of an organization (e.g. a municipality) using Internet concepts and tools (Turban, McLean and Wetherbe 2004:130; Averweg 2007:46). The cost efficiency of utilizing Internet technology has opened the door for organizations to use this same technology to share information within the organization (Botha 2004). IT thus plays an important role in organizations.

Tiwana and Ramesh (2001) contend that the intranet is well suited for use as a strategic tool within the domain of KM owing to its ability to support distribution, connectivity and publishing. According to these authors, the intranet should be seen as integral to an organization's KM strategy and should therefore be designed and tailored to enhance an organization's knowledge-sharing activities. This rationale raises the question as to whether an organization's existing intranet facilitates knowledge sharing and KM processes. The exploration of this question creates an opportunity for practitioner-based inquiry research within a field of application that seems particularly appealing: a metropolitan municipality eThekwini Municipality in Durban, South Africa. The appropriate context and appeal arose from the fact that the author (IT research analyst) is situated within the organization's Information Services Department. Given the author's position and eThekwini Municipality's IDP, this study was considered pertinent and relevant. In surveying the parameters of the question, the overriding premise was established as follows: If knowledge is used effectively, it may well provide meaningful utility to the organization. Clark (2001:189) notes that 'knowledge management initiatives are unlikely to be successful unless they are integrated with business strategy'.

Intranets create a common communications and information-sharing system. Brelade and Harman (2003) suggest that intranets can be used on a 'push' basis, where information is presented to employees, and on a 'pull' basis, where employees may seek out and retrieve information for themselves. These mechanisms are described more fully as follows:

- 'Push' technology is used when it is important that certain material be presented to employees at their workstation. It ensures that no other function takes place until all 
the information is correctly accessed.

- 'Pull' technology allows employees to decide when to pull down information that they wish to view from the intranet. The 'views of the end users are more important than in most other studies' (Skok and Kalmanovitch 2005:736).

To provide a seamless experience between viewing pages on the Web and viewing information on an intranet, access is usually via a standard Internet browser. The commonly used Internet browser in eThekwini Municipality is Microsoft Internet Explorer.

\section{Knowledge and managing knowledge}

The question of defining knowledge has occupied the minds of philosophers since the classical Greek era and has led to many epistemological debates (Alavi and Leidner 2001:109). What is knowledge? Geisler (2008) suggests that this can be answered in three different yet complementary streams:

- The way in which knowledge is structured

- To examine the nature of the dynamics and progress of knowledge

- To examine the uses of knowledge in the lives of individuals and how they apply their knowledge to their involvement in the economy and social affairs of their communities. It is argued by the author that this third stream include business organizations.

Many current theories and practices indicate that knowledge (and the management thereof) may prove useful if the scope and utility of knowledge is aligned with an organization's business strategy. For this reason managing knowledge and KM must have a business focus. It is therefore critical that KM aligns with the organization's business strategy and that it is structured in such a way that it articulates with the organization's purpose and goals. It may be further argued that knowledge should be viewed as a resource in the organization and that it should therefore tie in with the resource-based approach to an organization's business strategy.

Although this article seeks to review the role of the intranet and its contribution to knowledge-sharing within a KM strategy, it also proposes that KM should be set on a broader scale than merely IT, that is, it is argued that the management of knowledge should go beyond a narrow technical focus and encompass other less tangible themes within an organization. Zack (1999:125) clarifies the intangible 'as the knowledge existing within people's heads, augmented or shared via interaction and social relationships'. In this article, the technology, the notion of shared interaction and the creation of an opportunity for knowledge transfer are drawn together.

The basic role of technology in KM can be briefly summarized in functional terms into the areas of:

- Facilitating communication

- Enabling collaboration

- Collecting information

- Storing information

- Analysing information

- Disseminating information

- Updating information (Brelade and Harman 2003). 
top

\section{Knowledge management (KM)}

KM describes 'the primary focus of these efforts has been developing new applications of information technology to support digital capture, storage, retrieval and distribution of an organization's explicitly documented knowledge' (Zack 1999:125). In this article it is argued that, when aligned, organizational business strategy and technical resources (e.g. IT) provide a sound framework to support KM within an organization. KM must be guided by a strategic vision fully aligned with the strategic objectives of an organization (Stamou and Kollias 2005). However, the question arises as to whether an organization is making the best investment in its IT resources and whether it is managing knowledge in the right way. One technical IT resource in an organization is an intranet. From a survey of the IT literature, many research studies have focused on the intranet (see, for example, Curry and Stancich 2000; Tiwana and Ramesh 2001; Stenmark 2002; Brelade and Harman 2003; Van der Walt, Van Brakel and Kok 2004; Averweg 2007).

Precisely what is KM? Kwalek (2004:23) suggests that 'the literature on knowledge management is disjointed and disconnected'. Pfeffer and Sutton (2000:22) indicate that KM 'tends to treat knowledge as a tangible thing, as a stock or quantity, and therefore separates knowledge as some thing from the use of that thing'. While there are different views on what $\mathrm{KM}$ is, Nomura (2002:266) suggests that the 'objective of KM is to directly enhance corporate value according to business strategy'. From a review of the literature and for the purposes of this research, the following definition of KM was adopted: 'KM is the organisational process for acquiring, organising and communicating both tacit and explicit knowledge (so that people may use it to be more effective)' (Gray 2006:118). The argument for this selection is based on the recognition that the combined knowledge and expertise of employees within an organization is what makes an organization unique. It allows employees to add value so that they become more effective in an organization.

$\mathrm{KM}$ is not a centralized database that contains all the information known by an organization's workers. It is the idea of gaining business insights from a variety of sources including databases, Websites, employees and business partners - and cultivating that information wherever it resides into corporate value. Business insight emanates from capturing information and giving it greater meaning via its relationship to other information in the organization. It should be stated that $\mathrm{KM}$ is not about making plug-and-play workers dispensable because all they know is recorded for the next person who fills their shoes - it is about delivering information to knowledge workers, business processes and technology to make organizations and people successful and effective. The intranet, the in-house version of the Web browser based on Internet technology, creates a common corporate communications and information-sharing system (Brelade and Harman 2003).

\section{6 eThekwini Municipality in South Africa}

eThekwini Municipality comprises six clusters or service units (Office of the City Manager, Treasury, Governance, Sustainable Development and City Enterprises, Corporate and Human Resources and Health, Safety and Social Services) and employs approximately 20000 employees.

The Information Services Department is located in the Office of the City Manager. eThekwini Municipality has 6000 networked desktops (personal computers, thin clients and laptops) and electronic communication (i.e. e-mail) takes place via Novell's GroupWise 
(client version 6.5). A total of 6654 GroupWise accounts exist in the eThekwini Municipality. There are approximately 1500 Internet accounts utilizing either Microsoft Internet Explorer or Netscape Navigator Web browsers. The retention of institutional knowledge is seen as a key factor in the development of eThekwini Municipality becoming a 'smart city'.

\section{Research methodology}

There was a genuine need to explore the real-life phenomenon of whether eThekwini Municipality's intranet facilitated knowledge sharing. During this inquiry, the author was mindful that practitioner research should be self-reflective and critical.

Since the research was varied, disparate approaches were taken. For this research, a mixedmethods research approach was adopted by the practitioner:

- Knowledge claim - pragmatism

- Strategy of inquiry - transformative procedures

- Methods of data collection and analysis - secondary data and analysis were used.

For this mixed methods research methodology, the researcher made use of a theoretical lens or perspective to guide the study. The practitioner used the theory inductively (as in qualitative research) and deductively (as in quantitative research).

The intranet survey on which the researcher reports was practitioner-oriented knowledge. The researcher's survey design, process and results are presented as an exemplar of practitioner-oriented knowledge and should be seen in the context of informing the researcher's study. While this study was a practitioner-based inquiry, the author was mindful of 'the threats to the quality of ... [the] data by being too close to ... [the] research setting' (Saunders, Lewis and Thornhill 2006:99).

\section{Research method}

The data for the eThekwini Municipality's intranet were collected by an independent research company, Ask Africa. The rationale for using secondary data was that:

- The data were considered relevant to the study

- There were savings of time and money by using available data rather than collecting original data.

The researcher had to find a compromise between the ideals of good research and the numerous practical constraints that presented themselves in real-life research settings (Terre Blanche and Durrheim 1999:36). Such real-life research settings were suited to practitionerbased inquiries and were adopted by the author.

On 13 June 2006 eThekwini Municipality employees were invited - by e-mail invitation from the Communications Department - to participate in an online intranet survey. The aim of the survey was 'to identify areas where the intranet may need improvements' and 'to allow positive user experiences to be obtained'. eThekwini Municipality employees who expressed an interest in participating in this survey received an online questionnaire, which was emailed to them by Ask Africa's research partner, MicroIces. Data collation was handled by 
Ask Africa. The data used in this research were sourced from the eThekwini Municipality intranet Research Report (Ask Africa 2006), which was compiled by Ask Africa. The reported findings informed this study.

From the 150 e-mails sent to eThekwini Municipality employees, 39 responses were received. This represented $26 \%$ of the total number of employees who originally expressed interest in participating in the survey. Debowski (2006:274) suggests that response 'rates as low as $20 \%$ may still provide some sense of the issues'. The author did not participate in this online survey.

$\underline{\text { top }}$

\section{Results and discussion}

Extracted from the eThekwini Municipality Intranet Research Report (Ask Africa 2006), the results are now presented. The ranking in ascending order of Agree/Strongly agree responses to benefits the intranet holds is reflected in Table 1 .

Table 1 Ranking in ascending order of Agree/Strongly agree responses to benefits the intranet holds [adapted from eThekwini Municipality Intranet Research Report compiled by Ask Africa (2006:26)]

\begin{tabular}{|l|c|c|c|}
\hline \multirow{2}{*}{ Statement } & \multicolumn{3}{|c|}{$\begin{array}{c}\text { Percentage (\%) of } \\
\text { respondents (N= 19) }\end{array}$} \\
\cline { 2 - 4 } & $\begin{array}{c}\text { Agree/ } \\
\text { Strongly } \\
\text { agree }\end{array}$ & Neutral & Disagree \\
\hline $\begin{array}{l}\text { Useful platform to share and access inter- } \\
\text { departmental information }\end{array}$ & $87 \%$ & $9 \%$ & $4 \%$ \\
\hline $\begin{array}{l}\text { The intranet is an effective way to conduct } \\
\text { organizational interaction }\end{array}$ & $81 \%$ & $14 \%$ & $5 \%$ \\
\hline $\begin{array}{l}\text { Quickest focal point to disseminate and get } \\
\text { organizational communication }\end{array}$ & $77 \%$ & $14 \%$ & $9 \%$ \\
\hline Enhances departmental communication & $72 \%$ & $5 \%$ & $24 \%$ \\
\hline $\begin{array}{l}\text { Helps the organization improve its service to } \\
\text { customers }\end{array}$ & $65 \%$ & $15 \%$ & $20 \%$ \\
\hline Helps with productivity & $63 \%$ & $14 \%$ & $23 \%$ \\
\hline $\begin{array}{l}\text { Using the Intranet is necessary for employees to } \\
\text { perform daily work functions }\end{array}$ & $50 \%$ & $5 \%$ & $45 \%$ \\
\hline
\end{tabular}

From Table 1, the greatest perceived benefit that the intranet held for employees using it was as a platform to share and access inter-departmental (i.e. clusters or service units) information. The second highest reported benefit was as 'an effective way to conduct organisational interaction'. The third highest reported benefit was as the quickest 'focal point to disseminate and get organisational communication'. The lowest reported benefit was for employees to use the intranet for their daily work functions. Van der Walt, Van Brakel and Kok (2004:4) emphasize the importance of evaluating an organization's intranet to ascertain its 'future potential of the knowledge-sharing capability' of an organization.

The ranking in ascending order of Agree/Strongly agree responses to the design of the intranet is reflected in Table 2 . 
Table 2 Ranking in ascending order of Agree/Strongly agree responses to the design of the intranet [Adapted from eThekwini Municipality Intranet Research Report compiled by Ask Africa (2006:34)]

\begin{tabular}{|l|c|c|c|}
\hline \multirow{2}{*}{ Statement } & \multicolumn{3}{|c|}{$\begin{array}{c}\text { Percentage (\%) of } \\
\text { respondents (N= 21) }\end{array}$} \\
\cline { 2 - 4 } & $\begin{array}{c}\text { Agree/ } \\
\text { Strongly } \\
\text { agree }\end{array}$ & Neutral & Disagree \\
\hline I am happy with the text and font used on the site & $86 \%$ & $5 \%$ & $10 \%$ \\
\hline I am happy with the colours used on the site & $81 \%$ & $10 \%$ & $10 \%$ \\
\hline $\begin{array}{l}\text { I am happy with the layout and organization of } \\
\text { the site }\end{array}$ & $67 \%$ & $19 \%$ & $14 \%$ \\
\hline $\begin{array}{l}\text { I am happy with the images and pictures used on } \\
\text { the site }\end{array}$ & $62 \%$ & $19 \%$ & $19 \%$ \\
\hline $\begin{array}{l}\text { Overall I am happy with the design of the } \\
\text { intranet Website }\end{array}$ & $57 \%$ & $33 \%$ & $10 \%$ \\
\hline
\end{tabular}

From Table 2, it appears that most respondents surveyed (86\%) were satisfied with the text, font and colours used, but there was some disagreement on the images, pictures and overall design of the intranet Website. For respondents surveyed, this suggests that images and pictures used on the Website required improvement for the eThekwini Municipality employees to obtain user satisfaction (Ask Africa 2006: 35).

The ranking in ascending order of Agree/Strongly agree responses to the usability of the intranet is reflected in Table 3 .

Table 3 Ranking in ascending order of Agree/Strongly agree responses to the usability of the intranet [adapted from eThekwini Municipality Intranet Research Report compiled by Ask Africa (2006:39)]

\begin{tabular}{|l|c|c|c|}
\hline \multirow{2}{*}{ Statement } & \multicolumn{3}{|c|}{$\begin{array}{c}\text { Percentage (\%) of } \\
\text { respondents }(\mathbf{N}=\mathbf{2 0})\end{array}$} \\
\cline { 2 - 4 } & $\begin{array}{c}\text { Agree/ } \\
\text { Strongly } \\
\text { agree }\end{array}$ & Neutral & Disagree \\
\hline The drop-down menus are easy to use & $70 \%$ & $20 \%$ & $10 \%$ \\
\hline $\begin{array}{l}\text { Overall I am happy with the } \\
\text { functionality/usability of the site }\end{array}$ & $67 \%$ & $10 \%$ & $24 \%$ \\
\hline I am happy with the site labeling & $62 \%$ & $19 \%$ & $19 \%$ \\
\hline I am happy with the speed of the site & $62 \%$ & $14 \%$ & $24 \%$ \\
\hline I am able to navigate quickly and easily & $50 \%$ & $20 \%$ & $30 \%$ \\
\hline $\begin{array}{l}\text { The site is self-explanatory - it indicates where I } \\
\text { need to go to find the information I am looking } \\
\text { for }\end{array}$ & $43 \%$ & $29 \%$ & $29 \%$ \\
\hline
\end{tabular}

From Table 3, it appears that navigation improvements were required. Furthermore, while respondents surveyed agreed that they were able to navigate the intranet Website quickly and easily, they felt that there was no clear direction provided. This suggests that the navigation 
needed to be improved for beginner users so that they would have a better indication of where to go to find the information they were seeking (Ask Africa 2006: 41).

The ranking in ascending order of Agree/Strongly agree responses to the content of the Intranet is reflected in Table 4.

Table 4 Ranking in ascending order of Agree/Strongly agree responses to the content of the intranet [adapted from eThekwini Municipality Intranet Research Report compiled by Ask Africa (2006:44)]

\begin{tabular}{|l|c|c|c|}
\hline \multirow{2}{*}{ Statement } & \multicolumn{2}{|c|}{$\begin{array}{c}\text { Percentage (\%) of } \\
\text { respondents (N = 18) }\end{array}$} \\
\cline { 2 - 4 } & $\begin{array}{c}\text { Agree/ } \\
\text { Strongly } \\
\text { agree }\end{array}$ & Neutral & Disagree \\
\hline $\begin{array}{l}\text { The information and content on the Website is } \\
\text { relevant }\end{array}$ & $63 \%$ & $11 \%$ & $26 \%$ \\
\hline The information on the Website is reliable & $61 \%$ & $17 \%$ & $22 \%$ \\
\hline $\begin{array}{l}\text { Overall I am happy with the quality of content } \\
\text { on the Website }\end{array}$ & $57 \%$ & $14 \%$ & $29 \%$ \\
\hline I am happy with the quality of the search process & $57 \%$ & $14 \%$ & $33 \%$ \\
\hline The content on the site is regularly updated & $53 \%$ & $11 \%$ & $38 \%$ \\
\hline $\begin{array}{l}\text { There is a high likelihood of finding information } \\
\text { I am looking for even though I do not know } \\
\text { where to find it }\end{array}$ & $52 \%$ & $10 \%$ & $38 \%$ \\
\hline
\end{tabular}

From Table 4, it appears that respondents surveyed felt that the information on the Intranet was relevant and reliable. However, improvements in the updating of information and the quality of information seeking were required. This suggests that while the information on the Intranet Website was generally seen to be reliable, the regular updating of content and finding information that an employee was looking for needed to be improved (Ask Africa 2006:45). Van der Walt, Van Brakel and Kok (2004:17) suggest that employees should be 'motivated in various ways, so that they can see and experience the value they could add and receive by using the intranet for knowledge-sharing activities'.

An important use of most Intranets is to find documents that 'point' to employees who have knowledge and expertise. Wells, Sheina and Harris-Jones (2000) indicate that less than 5\% of employee knowledge is actually captured and accessible across the organization. Intranet satisfaction is directly influenced by having the right content, features and design factors (Kaplan 2001:1). In the case of knowledge-based applications, the benefits 'are the integration of heterogeneous information sources, which can improve interoperability, and more effective reuse of knowledge resources' (Stamou and Kollias 2005).

From the survey results, there appear to be areas for development improvement in the intranet design, usability and content areas. A post-study discussion describing why this was the case suggested that:

- The intranet should be more widely accessible to employees

- The intranet should encompass a wider range of language options

- User functionality might need improvement

○ Drop-down speeds should be increased 
- Intranet training programmes might need to be implemented

o Information should not be pocketed in silos of the organization

o Recency of information should be addressed.

IT is one foundation of KM (Stamou and Kollias 2005). An intranet may be classified as a $\mathrm{KM}$ application since it is capable of distributing knowledge. An intranet is seen as a tool for the more efficient sharing and creation of knowledge within organizations, using both 'push' and 'pull' technologies. However, in the case of the eThekwini Municipality's intranet, it appears that far greater use was made of the 'pull' technology (as opposed to 'push' technology). This trend would need to be addressed so that the 'pull' technology could also be facilitated.

The reported results tend to suggest that there was limited knowledge sharing and/or KM in eThekwini Municipality. The trend would also need to be addressed so that 'knowledge management [could be] a planned structured approach to manage the creation, sharing, harvesting and leveraging of knowledge as an organizational asset ... [and could] be in line with its business strategy' (Du Plessis and Boon 2004:75).

Organizational KM has been identified as a strategic tool for organizations (Stamou and Kollias 2005). Organizations generally make use of one of a variety of methodologies, or a combination of these, for strategy formulation when planning their longer term interaction with the environment. Knowledge-based strategy places the organization's primary intangible asset, namely the competence of its employees, at the centre.

\section{Conclusion}

Given the eThekwini Municipality's IDP and its overall intent to respond to social and economic needs of citizenry, the value of knowledge to organizational effectiveness is crucial. IT, with the enabling role of intranet technology, should be seen as significantly important to enhance the meaning and value of knowledge sharing within the eThekwini Municipality. This will serve to facilitate Programme 7 of SFA1 of the eThekwini Municipality's IDP. With the management of knowledge being aligned to the organizational business strategy, the intranet will provide a sound framework to support knowledge sharing within the eThekwini Municipality and become a strategic tool within a KM strategy.

The wheel of learning consists of question, theory, test and reflection (Handy 1989). Practitioner-generated research is the way a field's content (such as in this article) will commonly be produced and out of which theories about practice can be formulated. These academic theories about practice can then serve as a way for future practitioners in the knowledge-sharing field to learn and apply new knowledge to current and future KM practice. The author bases his comments on his active participation in contents and contribution to academic conferences and journals, and this practitioner-based inquiry. These are two different research traditions and it is contended that each field can learn from the other. When this practitioner reflects thereon, it is suggested that encouragement be given for more practitioner-based inquiry research.

\section{References}

Alavi, M. and Leidner, D.E. 2001. Review: Knowledge management and knowledge management systems: conceptual foundations and research issues. MIS Quarterly 25(1):107- 
136.

Ask Africa, 2006. eThekwini Municipality Intranet Research Report, 1-72, July (Unpublished).

Averweg, U. 2007. Impact of organisational intranets on profitability in organisations. In: Lubbe, S. (ed.). Managing information communication technology investments in successful enterprises 44-78. Hershey: Idea Group Publishing.

Bevan, R.M. 2006. Turbulent flow into smooth streams: transferring research knowledge between academic environments and practitioner contexts. Reflecting Education 2(1):55-72.

Botha, J. (ed.). 2004. Managing e-commerce. Lansdowne, South Africa: Juta \& Co.

Brelade, S. and Harman, C. 2003. Knowledge management - the systems dimension. London: Thorogood.

Clark, T. 2001. The knowledge economy. Education \& Training 43(4/5):189-196.

Curry, A. and Stancich, L. 2000. The intranet - an intrinsic component of strategic information management? International Journal of Information Management 20:249-268.

Debowski, S. 2006. Knowledge management. Milton: John Wiley \& Sons.

Du Plessis, M. and Boon, J.A. 2004. Knowledge management in eBusiness and customer relationship management: South African case study findings. International Journal of Information Management 24:73-86.

eThekwini Municipality, 2006. Innovations - good practice from the eThekwini Municipality, Durban, South Africa. Durban, South Africa: Corporate Policy Unit (CPU), eThekwini Municipality.

eThekwini Municipality Integrated Development Plan, 2007. 2010 and beyond. 2007-2008 review. Durban, South Africa: Corporate Policy Unit, eThekwini Municipality, 1-120.

Geisler, E. 2008. Knowledge and knowledge systems. Section 1 - the structure of knowledge. Hershey: IGI Publishing.

Gray, P. 2006. Manager's guide to making decisions about information systems. Hoboken: John Wiley \& Sons, Inc.

Hahn, J. and Subramani, M.R. 2000. A framework of knowledge management systems: issues and challenges for theory and practice. In: Proceedings of the twenty-first international conference on Information Systems 302-312.

Handy, C. 1989. The age of unreason. London: Arrow.

Kankanhalli, A., Tanudidjaja, F., Sutanto, J. and Tan, B.C.Y. 2003. The role of IT in successful knowledge management initiatives. Communications of the ACM 46(9): 69-73.

Kaplan, M. 2001. Intranets and corporate portals: user study. Agency.com Report. [Online]. Available WWW: http://knowledgemanagement.ittoolbox.com/documents/document.asp? $\mathrm{i}=1557$ (Accessed 14 January 2008). 
Khosrow-Pour, M. (ed.). 2005. Knowledge management - knowledge management on the Web. Encyclopedia of Information Science and Technology, Volume III. Hershey: IGI Publishing.

Kwalek, J.P. 2004. Systems thinking and knowledge management: positional assertions and preliminary observations. Systems Research and Behavioral Science 21:17-36.

McCutcheon, G. and Jung, B. 1990. Alternative perspectives on action research. Theory into Practice 29(3).

Nomura, T. 2002. Design of 'Ba' for successful knowledge management: how enterprises should design the places of interaction to gain competitive advantage. Journal of Network and Computer Applications 25(4):263-278.

Pfeffer, J. and Sutton, R. 2000. The knowing-doing gap: how smart companies turn knowledge into action. Boston: Harvard Business School Press.

Saunders, M., Lewis, P. and Thornhill, A. 2006. Research methods for business students. USA: Prentice-Hall.

Skok, W. and Kalmanovitch, C. 2005. Evaluating the role and effectiveness of an intranet in facilitating knowledge management: a case study at Surrey County Council. Information \& Management 42:731-744.

Skyrme, D.J. 1998. Developing a knowledge strategy. Strategy, January.

Stamou, G. and Kollias, S. 2005. Multimedia content and the semantic Web. Chapter $10-$ Semantic Web applications. USA: John Wiley \& Sons.

Stenmark, D. 2002. Information vs knowledge: the role of intranet in knowledge management. In: Proceedings of the 35th Hawaii International Conference on System Sciences (HICSS-35).

Terre Blanche, M. and Durrheim, K. 1999. Research in practice: applied methods for the social sciences. Cape Town: University of Cape Town Press.

Tiwana, A. and Ramesh, B. 2001. Integrating knowledge on the Web. IEEE Internet Computing 5(3):32-39.

Turban, E., McLean, E. and Wetherbe, J. 2004. Information technology for management. transforming organizations in the digital economy. Hoboken: John Wiley \& Sons.

Van der Walt, C., van Brakel, P.A. and Kok, J.A. 2004. Knowledge sharing via enterprise intranets - asking the right questions. South African Journal of Information Management 6 (2):1-12. Available WWW: http://www.sajim.co.za/default.asp?to=peervol6nr2 (Accessed 14 January 2008).

Wells, D., Sheina, M. and Harris-Jones, C. 2000. Enterprise portals: new strategies for information delivery 13(8), London: Ovum.

Zack, M.H. 1999. Developing a knowledge strategy. California Management Review 41 (3):125-146. 
ISSN 1560-683X

Published by InterWord Communications for Department of Information and Knowledge Management, University of Johannesburg 